\title{
Psychometric Testing of Shopping Mall Universal Design Assessment Tool (SM-UD)
}

\author{
Rebaz Jalil Abdullah \\ School of Architecture and Fine Art, Dalian University of Technology, Dalian 116024, China \\ Tang Jian \\ School of Architecture and Fine Art, Dalian University of Technology, Dalian 116024, China \\ Email: tangjian@dlut.edu.cn
}

\section{ABSTRACT}

While there are people with disability live in Kurdish parts of Iraq, a very limited number of buildings are properly designed to serve these people. Considering the challenges that people with disability face in public buildings, the United Nations has recommended the implementation of the Universal Design (UD) principles in public buildings in Iraq to ensure that all people could have access to the public buildings regardless of their abilities and backgrounds. Hence, there is a need to gather pertinent data by assessing the adherence of shopping malls in this part of Iraq to the Universal Design (UD) principles given the role of the facilities to the locals. The present study aims to develop a tool for assessing whether the shopping malls in Sulaymaniyah city adhere to Universal Design principles. An analytical tool, which was abbreviated as SM-UD, was developed using a wide range of shopping mall design elements. The tool was tested for reliability and validity through several statistical tests. Besides, the tool was tested for practicality and communicability in six different shopping malls of Sulaymaniyah. The reliability and validity test indicate that the majority of items showed good to excellent reliability and fair to excellent validity. The results of using the tool show that it is capable of identifying the drawbacks of shopping malls in terms of their universality of design. The proposed tool appears ready to be used by shopping malls' managers and researchers.
\end{abstract}

\author{
Article History \\ Received : 4 November 2019 \\ Received in revised form : 11 February 2020 \\ Accepted : 7 March 2020 \\ Published Online : 30 April 2020
}

Keywords:

Universal Design; Shopping malls; Sulaymaniyah city; assessment tool.

Corresponding Author Contact:

tangjian@dlut.edu.cn

DOI: $10.11113 /$ ijbes.v7.n2.497

\section{Introduction}

More than 1 billion people around the world suffer from various types of disability WHO (2013). This equals to nearly 15\% of the world's population. Countries like Iraq involved in several wars in the two recent decades. Thus, the higher number of People with Disability (PWDs) is expected in different parts of this country. Over 100 thousand PWDs live in Kurdish part of Iraq (European Network on Independent Living 2018). A recent report by the United Nations Assistance Mission for Iraq (UNAMI 2016) determined the PWDs challenges in Iraq and proposed a number of solutions to alleviate the PWDs daily challenges.
This report considered the huge number of PWDs in Iraq as a serious issue and emphasized on the necessity of implication of implication of Universal Design (UD) across the Iraq to ensure the accessibility of different places to the PWDs.

Broadly speaking, UD is a design concept that attempts to accommodate a broader range of users irrespective of their backgrounds and abilities (Baer, Bhushan et al. 2016). Despite the development of several UD guidelines across the globe, very limited number of assessment tools are available which measure the adherences of the built environments to the UD principles. Several public places such as malls, parks, hospitals, and so on are needed to be inspected to ensure these places are suitable for PWDs, children, and seniors. 
Shopping mall is an important part of urban life in cities of developing countries. There are several shopping malls in the Kurdish part of Iraq, which have not been assessed for adherence to the UD principles. Literature also confirms that, to date, there is no systematic approach to assess the suitability of shopping malls in Iraq, particularly the Kurdish Part (Jalil Abdullah and Jian 2019). This paper presents a part of wider research endeavor to leverage the use of UD in the design and assessment of shopping malls in Kurdish part of Iraq. The authors identified and confirmed the contributory design factors of shopping malls to the UD principles in Jalil Abdullah and Jian (2019). In this paper, the authors aim to illustrate the development process of a tool for assessing the shopping malls in Kurdish part of Iraq based on UD concept. This paper is structured as follows. The next section reviews definition and its principles of the UD and its translation into the shopping complex design criteria, reviews the existing design guidelines and standards of the UD in shopping malls, and the design factors of shopping malls. In method section, the mathematical modeling and case study are presented. We conclude the paper with some discussions and recommendations for future research.

\section{Background}

Story (1998) defined the Universal Design as the "design of products and environments that can be used and experienced by people of all ages and abilities, to the greatest extent possible, without adaptation". The UD has seven main principles, including equitable use, flexibility in use, simple and intuitive use, perceptible information, tolerance for error, low physical effort, and size and space for approach and use. However, implementation of these principles in practice is complicated (Story, Mueller et al. 1998).

UD has been applied in several fields of research, including but not restricted to education, production, and built environment design. Although more than two decades is passed from the proposing UD for different purposes, a very limited number of tools have been developed for assessing the adherence of the design or products to the UD principles. Stephanidis, Akoumianakis et al. (1998) proposed guidelines that were subsequently translated into key development requirements which were preserved in user interface development tools for them to provide the required support for building user interface software for different users and contexts of use. Lenker, Nasarwanji et al. (2011) developed the Rapid Assessment of Product Usability \& Universal Design (RAPUUD), a 12-item user-report tool based on the principles of universal design. Oh (2015) developed the design evaluation tool and guidelines of universal design for applying to the design of different spaces, including residential space, educational space, working space, and cultural space.

Concerning education, Fogarty (2017) proposed a clinical practice assessment tool to create access and equity for all students.

The body of literature is extremely thin regarding the implementation of UD in shopping malls. A number of studies attempted to identify problems of the application of restroom facilities, entrance and circulation facilities, and signage system to produce alternative solutions to those problems based on UD in the shopping centers of Surabaya, Indonesia (Kusumarini, de Yong et al. 2012, Kusumarini, de Yong et al. 2012, Kusumarini, de Yong et al. 2012). These studies used qualitative research and design thinking approach to assess the shopping malls. However, the qualitative approach of these studies might result in subjective assessment. Afacan and Erbug (2009) proposed a framework to heuristically evaluate the adherence of shopping malls to the UD principles. However, their proposed method was complicated and time-consuming.

More recently, Jalil Abdullah and Jian (2019) translated the general definition of UD into the shopping mall design criteria. In their translation, the shopping malls should be design in a way to accommodate all shoppers and visitors regardless of their backgrounds and abilities. Besides, the design of shopping malls should provide the shoppers with a usable, safe, and comfortable environment to the shoppers. They also used a structural equation modelling (SEM) to identify the most important shopping mall design factors based on UD. These factors are used in the present study to develop an easy to follow tool for assessing the adherence of the shopping malls to the UD principles.

Many countries around the world set the rules which ask the authorities of the public places follow the Universal Design principles. For example, the government of Dubai provides a detailed UD guideline in terms of built environment and transportation facilities (Dubai 2017). This UD guideline defines how the built environment and transportation systems in the Emirate should be designed, constructed and managed to enable one to approach, enter, use, egress from and evacuate independently, in an equitable and dignified manner, to the greatest extent possible, in line with the Universal Design concept. Many other countries across the globe also provide the same regulations and codes to the architectures, practitioners, and managers to serve all people regardless of their abilities and backgrounds.

More recently, the universal design principles have established in South Korea as a fundamental basis in developing and designing elderly residential houses, public spaces and public facilities. The knowledge of diversity for people especially in disability and elderly have been affected by universal design principles. The Universal Design removes all obstructions and encourages people to live, use and access all facilities easily without any barrier (Harsritanto, 2016).

Malaysian has also shown some development in catering to the need of persons with disabilities (PWD). Nevertheless, as appealed by Kamal Malhotra, the United Nations Resident Coordinator, in the National Conferences on "Accessibility and Universal Design: Implications for Public Transport and the Built Environment", yet, there is the need to efficiently implement universal design in Malaysia, the need for more professionals or 
researchers in this area, and the need to revisit the current standards codes. Thus, their study was called to enhance and complement the precedent studies that have been done on Malaysia accessibility issues and universal design implementation in public buildings (Kadir and Jamaludin 2012).

In recent years, in order to confirm the universal design and increased accessibility, many acts and regulations have been amended in Norway. The action plan is intended to support the implementation of the new Anti-Discrimination and Accessibility Act, new Planning and Building Act and other new legislation dealing with universal design. The action plan is also intended to help meet Norway's obligations when Norway ratifies the UN Convention on the Rights of People with disabilities. The government's vision that Norway is to be universally designed by 2025 can be achieved using various instruments that are adapted to suit the various sectors and tasks. Goals that are subject to deadlines are used (EQUALITY 2009).

\section{Method}

\subsection{Design Factors}

As pointed out earlier, the present paper is an extension of previous work aimed at translating the general definition of UD into the shopping mall design criteria and identifying the most important design factors of shopping malls based on UD principles, in a Kurdish context.

The authors conducted a literature review to first, translate the general definition of UD and its principles into the shopping complex design criteria; and second, to identify the widest range of design elements of shopping complexes and their contributions to the UD translated. The authors used expert opinions in two rounds. In the first round, the UD translated and the design elements identified were sent to a panel of experts who were asked to read and discuss the translations and the design elements. They were instructed to comment on each translation and design element, as well as to identify important elements that were missing or should be deleted.

Thus, the authors made some modifications based on the expert's comments. For example, in terms of UD translation and the new categorization, a number of unclear definitions (e.g., definitions of usability and comfort) were clarified to create a comprehensive theoretical classification. Concerning the design elements and their contribution to the UD translated aspects, the experts suggested that we add a number of design elements (e.g., stairs) to the list. The experts also considered more contributions of design elements to the UD translated aspects (usability, comfort, and safety). In fact, the experts confirmed that all the design elements identified have contributions to all three aspects of usability, comfort, and safety. The authors then used a Structural Equation Modelling (SEM) technique as a confirmatory analysis to determine the weighting of the stable extracted factors

Consequently, the authors have developed a tool using the design factors identified in Jalil Abdullah and Jian (2019), which are shown in Table 1. To develop the tool, we needed standards to compare the existing condition with the ideal condition. Thus, we have used some well-known UD guidelines that are widely available. In table 1, many UD standards are considered for each design factor.

Table 1 Tool items and standards

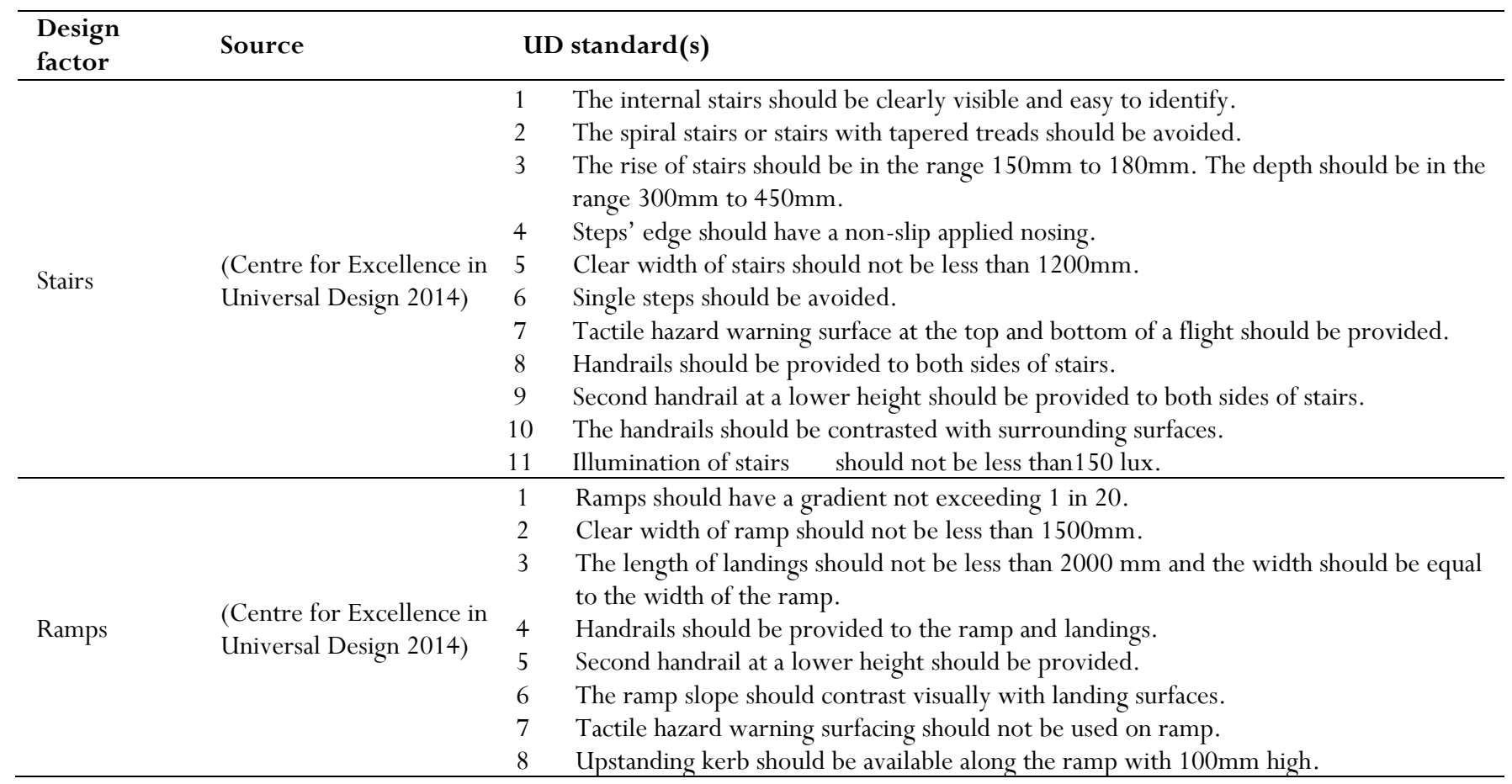




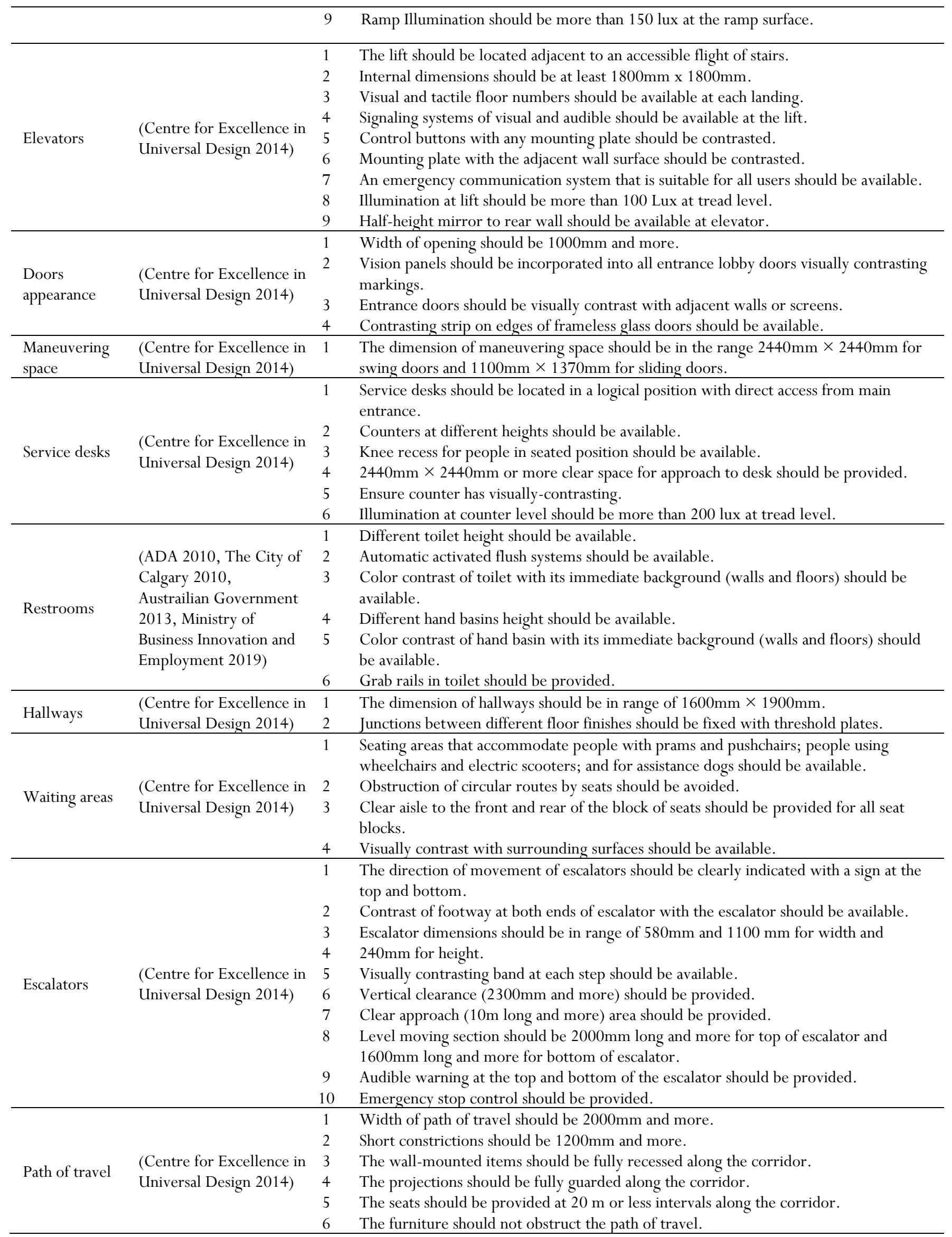




\begin{tabular}{llll}
\hline & $\begin{array}{l}\text { (Ministry of Business } \\
\text { Innovation and }\end{array}$ \\
$\begin{array}{l}\text { Architectural } \\
\text { wayfinding }\end{array}$ & $\begin{array}{l}\text { Employment 2019, } \\
\text { Ministry of Business } \\
\text { Innovation and } \\
\text { Employment 2019) }\end{array}$ & 2 & $\begin{array}{l}\text { Visual links with the outside should be provided on circulation routes. } \\
\text { Many glares in the internal environment should be provided. }\end{array}$ \\
\hline \multirow{3}{*}{$\begin{array}{l}\text { Graphical } \\
\text { wayfinding }\end{array}$} & $\begin{array}{l}\text { Innovation and } \\
\text { Employment 2019, }\end{array}$ & 1 & Visual, tactile and audible information in signage should be incorporated. \\
& $\begin{array}{l}\text { Ministry of Business } \\
\text { Innovation and }\end{array}$ & 2 & Signage should be clear, consistent, and easy to understand. \\
& Employment 2019) & & \\
\hline
\end{tabular}

\subsection{Mathematical Definition}

Mathematically, the SM-UD score can be defined as follows:

$\mathrm{SM}-\mathrm{UD}_{\text {score }}=\sum_{i=1}^{13} S_{j} W_{j}$

Here, SM-UD score $=$ shopping mall universal design score, $\mathrm{W}$ $=$ normalized weight of shopping mall indicator, $\mathrm{S}=$ indicator score, and $\mathrm{J}=$ indicator number.

The weight of each indicator is presented in Table 2. The weights were achieved in Jalil Abdullah and Jian (2019) that used a structural equitation modelling (SEM) technique to propose a model for shopping complex design based on Universal Design concept. According to this study, each shopping mall complex contributed in one or more aspects of Universal Design. The association value of each design factor with the UD aspect was considered as a weight. Then, for each design factor, the sum of the values was calculated and considered as the final raw weight. Finally, the raw weights were normalized to the range from 0 to 100 .

Table 1 Indicators' weight according to Jalil Abdullah and Jian (2019)

\begin{tabular}{llllll}
\hline Indicator & Usability & Safety & Comfort & Sum & $\begin{array}{l}\text { Normalized } \\
\text { Weight }\end{array}$ \\
\hline Stairs & 0.5 & 0.5 & 0.64 & 1.64 & 11.14 \\
\hline Ramps & 0.51 & & & 0.51 & 3.46 \\
\hline Elevators & 0.64 & 0.62 & 0.59 & 1.85 & 12.57 \\
\hline Doors appearance & 0.51 & 0.54 & 0.66 & 1.71 & 11.62 \\
\hline Maneuvering space & 0.51 & & 0.53 & 1.04 & 7.07 \\
\hline Service desks & 0.99 & 0.99 & 0.56 & 2.54 & 17.26 \\
\hline Restrooms & 0.82 & 0.59 & & 1.41 & 9.58 \\
\hline Hallways & & 0.51 & 0.55 & 1.06 & 7.20 \\
\hline Waiting & & 0.59 & & 0.59 & 4.01 \\
areas & & & 0.62 & 0.62 & 4.21 \\
\hline Escalators & & & 0.65 & 0.65 & 4.42 \\
\hline Path of travel & & & 0.51 & 0.51 & 3.46 \\
\hline $\begin{array}{l}\text { Architectural } \\
\text { wayfinding }\end{array}$ & & & & 0.59 & 4.01 \\
\hline Graphical wayfinding & & & & & \\
\hline
\end{tabular}

To achieve the SM-UD score, the S must be calculated. To assess each shopping mall design factor, one or more assessment items are proposed. The $\mathrm{S}$ for each shopping mall design factor is achieved by calculating the mean score from all assigned evaluators' assessment scores to the assessment items. Therefore, the factor assessment score is defined as follows:

$S_{j}=\frac{1}{n} \sum_{\substack{1 \leq i \leq n \\ 1 \leq j \leq 13}} M_{i j}$

Here, $\mathrm{S}=$ design factor assessment score, $\mathrm{M}=$ mean score of the statements within each design factor, $\mathrm{i}=$ number assigned to the assessment items (referring to Table 1), $\mathrm{j}=$ number assigned to the shopping mall design factor (referring to Table 3 ), and $n$ $=$ total number of assessment items within each shopping mall design factor.

Explaining the results of SM-UD by means of percentage facilitates the understanding of the SM-UD value. This percentage show scores that existing shopping malls can achieve from total possible points. The percentage of SM-UD is indicated as follows:

$\mathrm{SM}-\mathrm{UD} \%=\frac{\mathrm{K} \text {-UDS Score }}{\sum_{j=1}^{13} P S_{j} w_{j}} \times 100$

Here, PSJ = the highest possible score

Table 4 presents the different range of scores, descriptions, and required levels of improvement (RLI). SM-UD 'A' (80 $\leq$ SMUD $\% \leq 100)$ indicates that the shopping mall is in very good condition. SM-UD 'B' $(60 \leq$ SM-UD $\%<80)$ indicates that the shopping mall is in good condition and limited improvements are needed. SM-UD 'C' $(40 \leq$ SM-UD $\%<60)$ means the shopping mall condition is acceptable, but needs some improvements. SM-UD 'D' $(20 \leq$ SM-UD \% < 40) and 'E' $(0 \leq$ SM-UD $\%<20$ ) show that the shopping mall are in poor condition and not appropriate for using; these shopping malls need to get special attention to be improve 
Table 2 Assessment items of the shopping mall design factors

\begin{tabular}{|c|c|c|c|}
\hline Item ID & Assessment item & Item ID & Assessment item \\
\hline a & Circulation Elements - Stairs & f & Circulation Elements - Elevators \\
\hline a.1 & Visibility of stairs & f. 1 & Is the lift located adjacent to an accessible flight of stairs? \\
\hline a. 2 & Spiral stairs or stairs with tapered treads & f. 2 & Minimum internal dimensions of $1800 \mathrm{~mm} \times 1800 \mathrm{~mm}$ \\
\hline a. 3 & Steps' dimension & f. 3 & Visual and tactile floor numbers at each landing \\
\hline a.4 & Steps with projecting noising & f.4 & The lift signalling system is both visual and audible \\
\hline a. 5 & Clear width of stairs & f. 5 & Contrast of control buttons with any mounting plate \\
\hline a.6 & Single steps & f. 6 & Contrast of mounting plate with the adjacent wall surface \\
\hline a.7 & Tactile hazard warning surface at the top and bottom of a flight & f.7 & $\begin{array}{l}\text { An emergency communication system that is suitable for all } \\
\text { users. }\end{array}$ \\
\hline a. 8 & Handrails & f. 8 & Illumination at lift \\
\hline a.9 & Second handrail at a lower height & f. 9 & Half-height mirror to rear wall. \\
\hline a. 10 & Visual contrast of handrails with surrounding surfaces & g & Entering and Exiting Elements - Doors Appearance \\
\hline a.11 & Illumination of stairs & g.1 & Width of opening \\
\hline $\mathrm{b}$ & Circulation Elements - Ramps & g. 2 & Vision panels \\
\hline b. 1 & Ramps gradient & g. 3 & Visually contrasting markings \\
\hline b. 2 & Clear width of ramp & g.4 & Entrance doors contrast visually with adjacent walls or screens \\
\hline b. 3 & Landings dimensions & g.5 & Contrasting strip on edges of frameless glass doors \\
\hline b. 4 & Handrails & $\mathrm{h}$ & Entering and Exiting Elements - Maneuvering Space \\
\hline b. 5 & Second handrail at a lower height & h. 1 & Dimensions (pull side) \\
\hline b.6 & Contrast of ramp slop with landing surface & i & $\begin{array}{l}\text { Wayfinding Elements - Architectural Wayfinding (Overall } \\
\text { Assessment) }\end{array}$ \\
\hline b.7 & Tactile hazard warning surfacing on ramps & i. 1 & Provision of visual links with the outside \\
\hline b. 8 & Upstanding kerb & i. 2 & Glare in the internal environment \\
\hline b. 9 & Ramp Illumination & j & Wayfinding Elements - Graphical Wayfinding \\
\hline c & Circulation Elements - Escalators & j.1 & $\begin{array}{l}\text { Incorporation of visual, tactile and audible information in } \\
\text { signage }\end{array}$ \\
\hline c. 1 & Signage at the escalators & j.2 & Comprehension of signage \\
\hline c. 2 & Contrast of footway at both ends of escalator with the escalator & $\mathrm{k}$ & Obtaining Products and Services - Service Desks \\
\hline c. 3 & Escalator dimensions & k.1 & Location and access from main entrance \\
\hline c. 4 & Visually contrasting band at each step & $\mathrm{k} .2$ & Counters at different heights \\
\hline c. 5 & Vertical clearance & k.3 & Knee recess for people in seated position \\
\hline c. 6 & Clear approach area & k.4 & Provision of clear space for approach to desk \\
\hline c. 7 & Level moving section & k.5 & Ensure counter has visually-contrasting \\
\hline c. 8 & Audible warning at the top and bottom of the escalator & k.6 & Illumination at counter level \\
\hline c. 9 & Emergency stop control & l & Obtaining Products and Services - Waiting Areas \\
\hline d & Circulation Elements - Path of Travel & 1.1 & $\begin{array}{l}\text { Seating areas that accommodate people with prams and } \\
\text { pushchairs; people using wheelchairs and electric scooters; and } \\
\text { for assistance dogs }\end{array}$ \\
\hline d.1 & Width & 1.2 & Obstruction of circular routes by seats \\
\hline d.2 & Short constrictions & 1.3 & Clear aisle to the front and rear of the block of seats \\
\hline d. 3 & Recess of wall-mounted items & 1.4 & Visually contrast with surrounding surfaces \\
\hline d.4 & Guarding the projections into the clear width & $\mathrm{m}$ & Public Amenities - Restrooms \\
\hline d.5 & Seats along the corridor & $\mathrm{m} .1$ & Different toilet height \\
\hline d. 6 & Obstruction of travel path & $\mathrm{m} .2$ & Automatic activated flush systems \\
\hline e & Circulation Elements - Hallways & $\mathrm{m} .3$ & $\begin{array}{l}\text { Colour contrast of toilet with its immediate background (walls } \\
\text { and floors) }\end{array}$ \\
\hline e. 1 & Dimensions & $\mathrm{m} .4$ & Different hand basins height \\
\hline \multirow[t]{2}{*}{ e. 2} & Junctions between different floor finishes & m.5 & $\begin{array}{l}\text { Colour contrast of hand basin with its immediate background } \\
\text { (walls and floors) }\end{array}$ \\
\hline & & $\mathrm{m} .6$ & Grab rails in toilet \\
\hline
\end{tabular}


Table 3 SM-UD \% interpretation

\begin{tabular}{cccll}
\hline SM-UD \% & Grade & Condition & \multicolumn{1}{c}{ Description } & \multicolumn{1}{c}{$\begin{array}{c}\text { Level of required } \\
\text { improvements }\end{array}$} \\
\hline $80 \leq$ SM-UD $\% \leq 100$ & A & Very Good & $\begin{array}{l}\text { The shopping mall provides } \\
\text { excellent support for the } \\
\text { universal design principles }\end{array}$ & $\begin{array}{l}\text { Shopping mall needs very } \\
\text { limited improvements }\end{array}$ \\
\hline $60 \leq$ SM-UD \% $<80$ & B & Good & $\begin{array}{l}\text { The shopping mall provides adequately } \\
\text { support for the universal design principles }\end{array}$ & $\begin{array}{l}\text { Shopping mall needs limited } \\
\text { improvements }\end{array}$ \\
\hline $40 \leq$ SM-UD \% $<60$ & C & Regular & $\begin{array}{l}\text { The shopping mall provides partial support for } \\
\text { Universal Design principles }\end{array}$ & $\begin{array}{l}\text { Shopping mall needs some } \\
\text { improvements }\end{array}$ \\
\hline $0 \leq$ SM-UD $\%<40$ & D & Poor & $\begin{array}{l}\text { The shopping mall do not support the } \\
\text { universal design principles }\end{array}$ & $\begin{array}{l}\text { Shopping mall needs many } \\
\text { improvements }\end{array}$ \\
\hline 0 SM-UD $\%<20$ & E & Awful & $\begin{array}{l}\text { The shopping mall do not provide support for } \\
\text { Universal Design principles and for people } \\
\text { with disability }\end{array}$ & $\begin{array}{l}\text { Shopping mall needs too many } \\
\text { improvements }\end{array}$ \\
\hline
\end{tabular}

\subsection{Case Study}

The SM-UD tool was tested for communicability, practicality, reliability, and validity in six shopping malls, including City Center Mall, Majdi Mall, Caso Mall, Rand Gallery, and City star, which are the biggest shopping malls in Sulaymaniyah. These malls were built recently and based on our observations and informal conversations with their designers, the malls follow some principles of UD. However, their design is still not efficient enough since they consider a very limited number of UD features.

\subsection{Reliability And Validity}

The SM-UD tool was tested for reliability and validity. Reliability was tested through intra-rater and inter-rater reliability. Validity was also assessed through the criterion validity. Two evaluators (not including the first author) evaluated the case study using the SM-UD tool. Each rater assessed five zones on two separate occasions (period of 2 weeks between both ratings). The objectives of reliability tests were: (1) to assess the level of agreement over repeated measures and (2) to assess the level of agreement between team members (on first occasion). The reliability tests were conducted using PABAK kappa statistic (for Inter-rater reliability) and Cohens' kappa statistic (for Intra-rater reliability). To assess the criterion validity of SM-UD tool, the baseline degree of agreement for evaluators was investigated. On the first occasion that five zones of the case study were evaluated by two evaluators, the first author also evaluated these zones. For each evaluator, the degree of agreement was calculated with regard to the first author. The validity test was carried out using Cohens' kappa statistic.

\subsection{Testing Results}

To test the proposed tool, the authors split each case study into five zones. Each zone was evaluated by two evaluators for reliability tests, as well as testing the practicability of the tool. The Inter-rater reliability test was conducted based on two evaluators' ratings; Intra-rater reliability was carried out based on the one of evaluators' ratings in two different occasions; and the validity test compared the ratings of one of the evaluators with the first author ratings. The results of assessment also calculated based on the first author ratings.

\subsection{Reliability}

The results of reliability and validity tests are presented in Table 5. The ICC values show that six items had excellent reliability and six items had good reliability. The average Cohens' Kappa value of intra-rater reliability show that all items had excellent reliability. In addition, Cohens; kappa value of criterion validity indicate that two items had fair to good validity, and remains had excellent validity.

Table 4 Results of reliability and validity tests

\begin{tabular}{|c|c|c|c|}
\hline \multirow[t]{3}{*}{ Design factor } & $\begin{array}{l}\text { Inter-rater } \\
\text { reliability }\end{array}$ & $\begin{array}{l}\text { Intra-rater } \\
\text { reliability }\end{array}$ & $\begin{array}{l}\text { Criterion } \\
\text { validity }\end{array}$ \\
\hline & \multirow[t]{2}{*}{ Average ICC } & Average & Average \\
\hline & & Cohens' Kappa & Cohens' Kappa \\
\hline Stairs & 0.89 & 0.94 & 0.79 \\
\hline Ramps & 0.76 & 1.00 & 0.74 \\
\hline Escalators & 0.95 & 0.91 & 0.91 \\
\hline Path of travel & 0.81 & 0.82 & 0.63 \\
\hline Hallways & 1.00 & 1.00 & 1.00 \\
\hline Elevators & 0.89 & 1.00 & 0.82 \\
\hline $\begin{array}{l}\text { Doors' } \\
\text { appearance }\end{array}$ & 0.89 & 0.83 & 0.76 \\
\hline $\begin{array}{l}\text { Maneuvering } \\
\text { space* }\end{array}$ & - & - & - \\
\hline $\begin{array}{l}\text { Architectural } \\
\text { wayfinding }\end{array}$ & 1.00 & 1.00 & 1.00 \\
\hline $\begin{array}{l}\text { Graphical } \\
\text { wayfinding }\end{array}$ & 1.00 & 1.00 & 1.00 \\
\hline Service desks & 0.93 & 1.00 & 0.87 \\
\hline Waiting areas & 1.00 & 0.77 & 1.00 \\
\hline Restrooms & 0.83 & 0.87 & 0.75 \\
\hline \multicolumn{4}{|c|}{ *No statistics are computed. } \\
\hline \multicolumn{4}{|c|}{$\begin{array}{l}\text { ICC } \leq 0.5: \text { poor; } 0.5<\text { ICC } \leq 0.75: \text { moderate; } 0.75<\text { ICC } \leq 0.90 \text { : } \\
\text { good; ICC }>0.90: \text { excellent }(\text { Koo and Li 2016) }\end{array}$} \\
\hline
\end{tabular}




\section{Assessment Results}

The SM-UD\% is calculated for the City Center Mall (refer to Eq. 3). To obtain the SM-UD\% for each of the shopping mall design factors and overall SM-UD\% for the shopping mall, it is vital to determine the level of improvements of the shopping mall as a whole and the shopping mall design factors, in particular. Table 6 indicates the SM-UD\% for the selected shopping mall, and also the level of required improvements (LRI) for the shopping mall design factors and the whole shopping mall. According to Table 3, SM-UD\% of the shopping mall was 27.56; therefore, the grade of the universality design of the shopping mall was ' $\mathrm{D}$ ', which shows that the shopping mall do not support the universal design principles and needs many improvements. Among the shopping mall design factors, the factors that achieve 'poor' and 'awful' SM-UD\% need many and too many improvements, such as stairs, ramps, escalators, path of travel, hallways, elevators, doors' appearance, graphical wayfinding, service desks, waiting areas, restrooms, and architectural wayfinding. Only one design factor achieved 'regular' SM-UD\% in the selected shopping mall, which was maneuvering space and needed some little improvements. No design factors achieved "A" and "B" grades.

Table 5 SM-UD\% and condition of City Center Mall

\begin{tabular}{|c|c|c|c|c|c|c|c|}
\hline 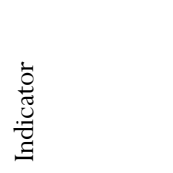 & 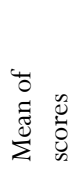 & 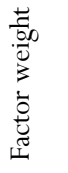 & $\begin{array}{l}0 \\
0 \\
0 \\
\infty \\
\sum_{\infty} \\
\sum_{\infty}^{1}\end{array}$ & $\begin{array}{l}0^{\circ} \\
ٍ \\
\sum_{n}^{\prime}\end{array}$ & $\frac{2}{\frac{\pi}{2}}$ & 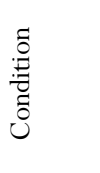 & $\vec{x}$ \\
\hline Stairs & 3.09 & $\begin{array}{c}11.1 \\
4\end{array}$ & $\begin{array}{c}34.4 \\
3\end{array}$ & $\begin{array}{c}34.0 \\
0\end{array}$ & $\mathrm{D}$ & Poor & 2 \\
\hline Ramps & 2.38 & 3.46 & 8.22 & $\begin{array}{c}26.7 \\
2\end{array}$ & $\mathrm{D}$ & Poor & 2 \\
\hline Escalators & 2.44 & $\begin{array}{c}12.5 \\
7\end{array}$ & $\begin{array}{c}30.7 \\
3\end{array}$ & $\begin{array}{c}33.8 \\
5\end{array}$ & $\mathrm{D}$ & Poor & 2 \\
\hline Path of travel & 2.83 & $\begin{array}{c}11.6 \\
2\end{array}$ & $\begin{array}{c}32.9 \\
2\end{array}$ & $\begin{array}{c}34.0 \\
0\end{array}$ & $\mathrm{D}$ & Poor & 2 \\
\hline Hallways & 1.50 & 7.07 & $\begin{array}{c}10.6 \\
1\end{array}$ & $\begin{array}{c}30.0 \\
0\end{array}$ & $\mathrm{D}$ & Poor & 2 \\
\hline Elevators & 1.78 & $\begin{array}{c}17.2 \\
6\end{array}$ & $\begin{array}{c}30.6 \\
8\end{array}$ & $\begin{array}{c}32.0 \\
0\end{array}$ & $\mathrm{D}$ & Poor & 2 \\
\hline $\begin{array}{l}\text { Doors' } \\
\text { appearance }\end{array}$ & 2.00 & 9.58 & $\begin{array}{c}19.1 \\
6\end{array}$ & $\begin{array}{c}22.2 \\
2\end{array}$ & $\mathrm{D}$ & Poor & 2 \\
\hline $\begin{array}{l}\text { Maneuvering } \\
\text { space }\end{array}$ & 5.00 & 7.2 & $\begin{array}{c}36.0 \\
0\end{array}$ & $\begin{array}{c}50.0 \\
0\end{array}$ & $\mathrm{C}$ & Regular & 3 \\
\hline $\begin{array}{l}\text { Architectural } \\
\text { way finding }\end{array}$ & 1.00 & 4.01 & 4.01 & $\begin{array}{c}10.0 \\
0\end{array}$ & $E$ & Awful & 1 \\
\hline $\begin{array}{l}\text { Graphical } \\
\text { way finding }\end{array}$ & 2.50 & 4.21 & $\begin{array}{c}10.5 \\
3\end{array}$ & $\begin{array}{c}25.0 \\
0\end{array}$ & $\mathrm{D}$ & Poor & 2 \\
\hline Service desks & 1.67 & 4.42 & 7.37 & $\begin{array}{c}25.0 \\
0\end{array}$ & $\mathrm{D}$ & Poor & 2 \\
\hline $\begin{array}{l}\text { Waiting } \\
\text { areas }\end{array}$ & 1.50 & 4.01 & 6.02 & $\begin{array}{c}17.1 \\
4\end{array}$ & $\mathrm{E}$ & Awful & 1 \\
\hline Restrooms & 1.83 & 3.46 & 6.34 & $\begin{array}{c}18.3 \\
3\end{array}$ & $\mathrm{E}$ & Awful & 1 \\
\hline
\end{tabular}

\begin{tabular}{lc}
\hline Overall SM-UD $\%$ & 27.56 \\
\hline Overall LRI & 2 \\
\hline Level of required improvement: LRI; shopping mall needs very \\
limited improvements=5; Shopping mall needs limited \\
improvements=4; shopping mall needs some improvements=3; \\
shopping mall needs many improvements=2; shopping mall needs \\
too many improvements=1
\end{tabular}

Tables 7-9 display the SM-UD\% of City Star, Rand Gallery, and Caso Mall in Sulaymaniyah. The SM-UD\% of these shopping malls was below 20; therefore, the grade of the universality design of the shopping mall was 'E', which shows that these shopping malls do not provide support for Universal Design principles and for people with disability. These malls need too many improvements to support Universal Design principles.

Table 6 SM-UD\% and condition of City Star

\begin{tabular}{|c|c|c|c|c|c|c|c|}
\hline 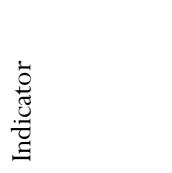 & 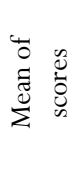 & 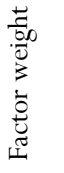 & $\begin{array}{l}0 \\
\vdots \\
0 \\
\infty \\
\vdots \\
\vdots \\
\sum_{\infty}^{\prime}\end{array}$ & $\sum_{\infty}^{\circ}$ & 节 & 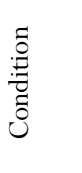 & $\ddot{\underline{a}}$ \\
\hline Stairs & 1.55 & $\begin{array}{c}11.1 \\
4\end{array}$ & $\begin{array}{r}17.2 \\
2\end{array}$ & $\begin{array}{c}17.0 \\
0\end{array}$ & $E$ & $\begin{array}{c}\text { Awfu } \\
1\end{array}$ & 1 \\
\hline Ramps & 0.97 & 3.46 & 3.34 & $\begin{array}{c}10.8 \\
7\end{array}$ & $\mathrm{E}$ & $\begin{array}{c}\text { Awfu } \\
1\end{array}$ & 1 \\
\hline Escalators & 0.89 & $\begin{array}{c}12.5 \\
7\end{array}$ & $\begin{array}{r}11.1 \\
7\end{array}$ & $\begin{array}{c}12.3 \\
1\end{array}$ & $E$ & $\begin{array}{c}\text { Awfu } \\
1\end{array}$ & 1 \\
\hline Path of travel & 1.50 & $\begin{array}{c}11.6 \\
2\end{array}$ & $\begin{array}{r}17.4 \\
3\end{array}$ & $\begin{array}{c}18.0 \\
0\end{array}$ & $E$ & $\begin{array}{c}\text { Awfu } \\
1\end{array}$ & 1 \\
\hline Hallways & 1.50 & 7.07 & $\begin{array}{r}10.6 \\
1\end{array}$ & $\begin{array}{c}30.0 \\
0\end{array}$ & $\mathrm{D}$ & Poor & 2 \\
\hline Elevators & 0.78 & $\begin{array}{c}17.2 \\
6\end{array}$ & $\begin{array}{r}13.4 \\
2\end{array}$ & $\begin{array}{c}14.0 \\
0\end{array}$ & E & $\begin{array}{c}\text { Awfu } \\
1\end{array}$ & 1 \\
\hline $\begin{array}{l}\text { Doors' } \\
\text { appearance }\end{array}$ & 1.60 & 9.58 & $\begin{array}{r}15.3 \\
3\end{array}$ & $\begin{array}{c}17.7 \\
8\end{array}$ & $\mathrm{E}$ & $\begin{array}{c}\text { Awfu } \\
1\end{array}$ & 1 \\
\hline $\begin{array}{l}\text { Maneuvering } \\
\text { space }\end{array}$ & 3.00 & 7.2 & $\begin{array}{r}21.6 \\
0\end{array}$ & $\begin{array}{c}30.0 \\
0\end{array}$ & $\mathrm{D}$ & Poor & 2 \\
\hline $\begin{array}{l}\text { Architectural } \\
\text { wayfinding }\end{array}$ & 1.50 & 4.01 & 6.02 & $\begin{array}{c}15.0 \\
0\end{array}$ & $E$ & $\begin{array}{c}\text { Awfu } \\
1\end{array}$ & 1 \\
\hline $\begin{array}{l}\text { Graphical } \\
\text { wayfinding }\end{array}$ & 1.00 & 4.21 & 4.21 & $\begin{array}{c}10.0 \\
0\end{array}$ & E & $\begin{array}{c}\text { Awfu } \\
1\end{array}$ & 1 \\
\hline Service desks & 2.00 & 4.42 & 8.84 & $\begin{array}{c}30.0 \\
0\end{array}$ & $\mathrm{D}$ & Poor & 2 \\
\hline $\begin{array}{l}\text { Waiting } \\
\text { areas }\end{array}$ & 2.00 & 4.01 & 8.02 & $\begin{array}{c}22.8 \\
6\end{array}$ & $\mathrm{D}$ & Poor & 2 \\
\hline Restrooms & 1.33 & 3.46 & 4.61 & $\begin{array}{c}13.3 \\
3\end{array}$ & E & $\begin{array}{c}\text { Awfu } \\
1\end{array}$ & 1 \\
\hline \multicolumn{4}{|c|}{ Overall SM-UD \% } & 18.55 & & & \\
\hline \multicolumn{8}{|c|}{$\begin{array}{l}\text { Level of required improvement: LRI; shopping mall needs very } \\
\text { limited improvements }=5 \text {; Shopping mall needs limited } \\
\text { improvements }=4 \text {; shopping mall needs some improvements }=3 \text {; } \\
\text { shopping mall needs many improvements }=2 \text {; shopping mall needs } \\
\text { too many improvements }=1\end{array}$} \\
\hline
\end{tabular}


Table 7 SM-UD\% and condition of Rand Gallery

\begin{tabular}{|c|c|c|c|c|c|c|c|}
\hline 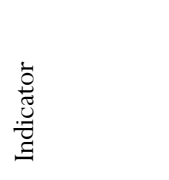 & 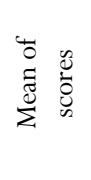 & 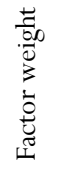 & 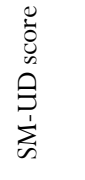 & $\begin{array}{l}0^{\circ} \\
\sum_{\infty}^{1}\end{array}$ & 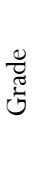 & 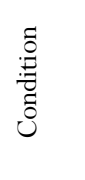 & $\vec{\beth}$ \\
\hline Stairs & 1.82 & 11.14 & 20.25 & 20.00 & E & Awful & 1 \\
\hline Ramps & 1.49 & 3.46 & 5.15 & 16.73 & $\mathrm{E}$ & Awful & 1 \\
\hline Escalators & 1.22 & 12.57 & 15.36 & 16.92 & E & Awful & 1 \\
\hline $\begin{array}{l}\text { Path of } \\
\text { travel }\end{array}$ & 1.67 & 11.62 & 19.37 & 20.00 & $\mathrm{E}$ & Awful & 1 \\
\hline Hallways & 2.00 & 7.07 & 14.14 & 40.00 & D & Poor & 2 \\
\hline Elevators & 1.00 & 17.26 & 17.26 & 18.00 & E & Awful & 1 \\
\hline $\begin{array}{l}\text { Doors' } \\
\text { appearance }\end{array}$ & 1.60 & 9.58 & 15.33 & 17.78 & $\mathrm{E}$ & Awful & 1 \\
\hline $\begin{array}{l}\text { Maneuvering } \\
\text { space }\end{array}$ & 3.00 & 7.2 & 21.60 & 30.00 & $\mathrm{D}$ & Poor & 2 \\
\hline $\begin{array}{l}\text { Architectural } \\
\text { wayfinding }\end{array}$ & 1.00 & 4.01 & 4.01 & 10.00 & E & Awful & 1 \\
\hline $\begin{array}{l}\text { Graphical } \\
\text { wayfinding }\end{array}$ & 0.50 & 4.21 & 2.11 & 5.00 & E & Awful & 1 \\
\hline Service desks & 1.67 & 4.42 & 7.37 & 25.00 & $\mathrm{D}$ & Poor & 2 \\
\hline $\begin{array}{l}\text { Waiting } \\
\text { areas }\end{array}$ & 2.00 & 4.01 & 8.02 & 22.86 & $\mathrm{D}$ & Poor & 2 \\
\hline Restrooms & 1.50 & 3.46 & 5.19 & 15.00 & E & Awful & 1 \\
\hline \multicolumn{4}{|c|}{ Overall SM-UD \% } & \multicolumn{3}{|c|}{19.79} & \\
\hline \multicolumn{4}{|c|}{ Overall LRI } & \multicolumn{3}{|c|}{1} & \\
\hline \multicolumn{8}{|c|}{$\begin{array}{l}\text { Level of required improvement: LRI; shopping mall needs very limited } \\
\text { improvements }=5 \text {; Shopping mall needs limited improvements=4; } \\
\text { shopping mall needs some improvements }=3 \text {; shopping mall needs } \\
\text { many improvements }=2 \text {; shopping mall needs too many } \\
\text { improvements }=1\end{array}$} \\
\hline
\end{tabular}

Table 8 SM-UD\% and condition of Caso Mall

\begin{tabular}{|c|c|c|c|c|c|c|c|}
\hline 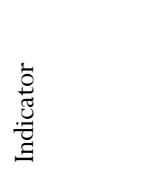 & 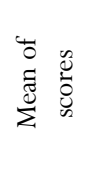 & 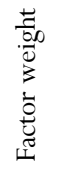 & $\begin{array}{l}0 \\
0 \\
0 \\
\infty \\
Ð \\
\sum_{\infty}^{\prime}\end{array}$ & 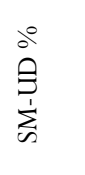 & $\frac{\mathscr{J}}{\tilde{J}}$ & $\begin{array}{l}\stackrel{0}{0} \\
\stackrel{0}{0} \\
0 \\
0\end{array}$ & $\bar{a}$ \\
\hline Stairs & 2.00 & 11.14 & 22.28 & 22.00 & $\mathrm{D}$ & Poor & 2 \\
\hline Ramps & 1.64 & 3.46 & 5.68 & 18.46 & $\mathrm{E}$ & Awful & 1 \\
\hline Escalators & 1.33 & 12.57 & 16.76 & 18.46 & E & Awful & 1 \\
\hline $\begin{array}{l}\text { Path of } \\
\text { travel }\end{array}$ & 2.00 & 11.62 & 23.24 & 24.00 & D & Poor & 2 \\
\hline Hallways & 1.00 & 7.07 & 7.07 & 20.00 & $\mathrm{D}$ & Poor & 2 \\
\hline Elevators & 0.78 & 17.26 & 13.42 & 14.00 & E & Awful & 1 \\
\hline $\begin{array}{l}\text { Doors' } \\
\text { appearance }\end{array}$ & 1.20 & 9.58 & 11.50 & 13.33 & E & Awful & 1 \\
\hline $\begin{array}{l}\text { Maneuvering } \\
\text { space }\end{array}$ & 3.00 & 7.2 & 21.60 & 30.00 & D & Poor & 2 \\
\hline $\begin{array}{l}\text { Architectural } \\
\text { wayfinding }\end{array}$ & 1.00 & 4.01 & 4.01 & 10.00 & E & Awful & 1 \\
\hline $\begin{array}{l}\text { Graphical } \\
\text { wayfinding }\end{array}$ & 2.50 & 4.21 & 10.53 & 25.00 & D & Poor & 2 \\
\hline Service desks & 1.67 & 4.42 & 7.37 & 25.00 & $\mathrm{D}$ & Poor & 2 \\
\hline $\begin{array}{l}\text { Waiting } \\
\text { areas }\end{array}$ & 2.00 & 4.01 & 8.02 & 22.86 & $\mathrm{D}$ & Poor & 2 \\
\hline Restrooms & 1.33 & 3.46 & 4.61 & 13.33 & E & Awful & 1 \\
\hline
\end{tabular}

\begin{tabular}{l}
\hline Overall SM-UD \% 19.73 \\
\hline Overall LRI \\
\hline Level of required improvement: LRI; shopping mall needs very limited \\
improvements=5; Shopping mall needs limited improvements=4; \\
shopping mall needs some improvements $=3$; shopping mall needs \\
many improvements=2; shopping mall needs too many \\
improvements=1
\end{tabular}

Tables 10 and 11 show the SM-UD\% of Family Mall and Majdi Mall in Sulaymaniyah. The SM-UD\% of these shopping malls was between 60 and 80; thus, the grade of the universality design of the shopping mall was ' $\mathrm{B}$ ', which shows that these shopping malls provide adequately support for the universal design principles. These malls need limited improvements to support Universal Design principles.

Table 9 SM-UD\% and condition of Family Mall

\begin{tabular}{|c|c|c|c|c|c|c|c|}
\hline 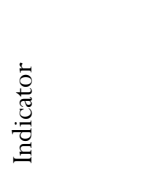 & $\begin{array}{ll}\overrightarrow{0} & w \\
\tilde{J} & 0 \\
\tilde{J} & 0 \\
\sum_{i} & 0\end{array}$ & 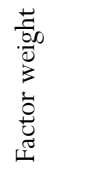 & $\underset{\substack{0 \\
0 \\
\infty}}{\sum_{\infty}^{1}}$ & $\stackrel{\circ}{0}_{\sum_{n}^{1}}^{1}$ & 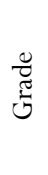 & 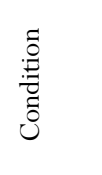 & $\widetilde{\Im}$ \\
\hline Stairs & $\begin{array}{c}6.0 \\
9\end{array}$ & 11.14 & 67.85 & 67.00 & B & Good & 4 \\
\hline Ramps & $\begin{array}{c}6.0 \\
4\end{array}$ & 3.46 & 20.91 & 67.98 & B & Good & 4 \\
\hline Escalators & $\begin{array}{c}5.4 \\
4\end{array}$ & 12.57 & 68.44 & 75.38 & B & Good & 4 \\
\hline $\begin{array}{l}\text { Path of } \\
\text { travel }\end{array}$ & $\begin{array}{c}5.3 \\
3\end{array}$ & 11.62 & 61.97 & 64.00 & B & Good & 4 \\
\hline Hallways & $\begin{array}{c}3.5 \\
0\end{array}$ & 7.07 & 24.75 & 70.00 & B & Good & 4 \\
\hline Elevators & $\begin{array}{c}3.2 \\
2\end{array}$ & 17.26 & 55.62 & 58.00 & $\mathrm{C}$ & $\begin{array}{c}\text { Regula } \\
\mathrm{r}\end{array}$ & 3 \\
\hline $\begin{array}{l}\text { Doors' } \\
\text { appearance }\end{array}$ & $\begin{array}{c}3.8 \\
0\end{array}$ & 9.58 & 36.40 & 42.22 & $\mathrm{C}$ & $\begin{array}{c}\text { Regula } \\
\mathrm{r}\end{array}$ & 3 \\
\hline $\begin{array}{l}\text { Maneuveri } \\
\text { ng space }\end{array}$ & $\begin{array}{c}7.0 \\
0\end{array}$ & 7.2 & 50.40 & 70.00 & B & Good & 4 \\
\hline $\begin{array}{l}\text { Architectu } \\
\text { ral } \\
\text { wayfinding }\end{array}$ & $\begin{array}{c}6.5 \\
0\end{array}$ & 4.01 & 26.07 & 65.00 & B & Good & 4 \\
\hline $\begin{array}{l}\text { Graphical } \\
\text { wayfinding }\end{array}$ & $\begin{array}{c}4.0 \\
0 \\
\end{array}$ & 4.21 & 16.84 & 40.00 & $\mathrm{C}$ & $\begin{array}{l}\text { Regula } \\
\mathrm{r}\end{array}$ & 3 \\
\hline $\begin{array}{l}\text { Service } \\
\text { desks }\end{array}$ & $\begin{array}{c}4.5 \\
0\end{array}$ & 4.42 & 19.89 & 67.50 & B & Good & 4 \\
\hline $\begin{array}{l}\text { Waiting } \\
\text { areas }\end{array}$ & $\begin{array}{c}6.0 \\
0\end{array}$ & 4.01 & 24.06 & 68.57 & B & Good & 4 \\
\hline Restrooms & $\begin{array}{c}4.1 \\
7 \\
\end{array}$ & 3.46 & 14.42 & 41.67 & $\mathrm{C}$ & $\begin{array}{c}\text { Regula } \\
\mathrm{r}\end{array}$ & 3 \\
\hline $\begin{array}{l}\text { Overall SM- } \\
\text { Overall LRI }\end{array}$ & ID \% & & & $\begin{array}{l}61.3 \\
4\end{array}$ & & & \\
\hline \multicolumn{8}{|c|}{$\begin{array}{l}\text { Level of required improvement: LRI; shopping mall needs very limited } \\
\text { improvements }=5 \text {; Shopping mall needs limited improvements=4; } \\
\text { shopping mall needs some improvements }=3 \text {; shopping mall needs } \\
\text { many improvements=2; shopping mall needs too many } \\
\text { improvements }=1\end{array}$} \\
\hline
\end{tabular}


Table 10 SM-UD\% and condition of Majdi Mall

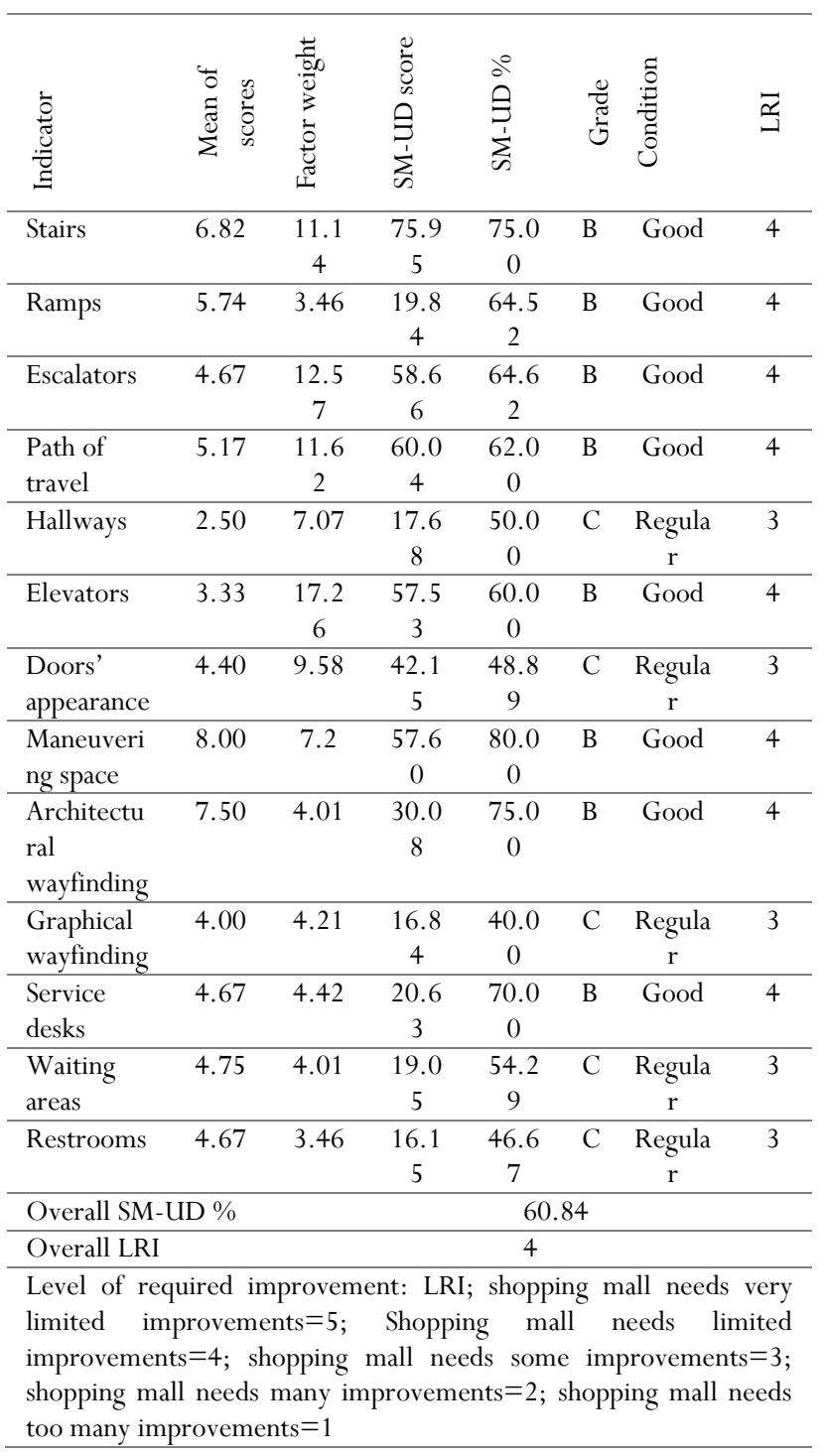

\section{Discussion and Conclusion}

This study was aimed to describe the developments and evaluation of a tool for assessment of universal design in shopping malls (SM-UD). A very limited number of assessment tools are available for assessing whether a public space adheres the Universal Design principles. The proposed tool assesses the universality design of shopping malls as an important component of cities. Since this tool is designed for Kurdistan, a wide range of shopping mall design factors were used based on Kurdish people perceptions. However, this broad spectrum of shopping mall design factors is capable of making this tool to be applicable in other countries with characteristics. In addition, SM-UD tool developed an easy-to-follow methodology for assessing universality design of different shopping malls. The inter-rater and intra-rater reliability tests were used to determine the reliability of the shopping mall design factors within SM-UD. In the selected shopping mall, all factors showed good and excellent reliability. As expected, the objective design factors obtained high reliability. The least Cohens' Kappa value for intra-rater reliability belonged to waiting areas (0.77). The possible explanation for this is inconsistency in the values of "obstruction of circular routes by seats", which somewhat requires a subjective judgment. Same subjectivity might cause that path of travel obtained the least (0.63) Cohens' Kappa value for criterion validity. Overall, the reliability and validity test results showed that all items of the tool exhibit good and stable psychometric properties. A simple check on the assessment results shows that the scores of the assessment items are consistent across the case studies. For example, waiting area in City Center Mall, which is very scarce in this shopping mall has obtained a SM-UD\% below 20, which shows the awful condition of this item in the shopping mall. In fact, the SM-UD\% of waiting area in the City Center Mall correspond with the observation survey in this case study. The consistency between the scores of assessment items and their condition in real world provides strong support for the validity of the tool assessment items.

The SM-UD tool is useful to architects, shopping malls' owners, and city planners for increasing the awareness about the universality design of the shopping malls. This tool also helps them to prioritize investments and upgrade the shopping mall facilities. Concerning the use of a wide range of design factors to assess the universality design of shopping malls, other researchers can use similar methodology and process to develop new assessment tools for other public spaces such as parks, hospitals, and so on. The proposed tool can be used in other countries with suitable modifications.

\section{References}

ADA. (2010). Americans with Disabilities Act (ADA) Accessibility Guidelines for Buildings and Facilities. In. Washington, D.C.: U.S. Architectural and Transportation Barriers Compliance Board,.

Afacan, Y., \& Erbug, C. (2009). An Interdisciplinary Heuristic Evaluation Method for Universal Building Design. Appl Ergon, 40(4), 731-744. doi:10.1016/j.apergo.2008.07.002

Austrailian Government. (2013). Accessibility Design Guide: Universal Design Principles for Australia's Aid Program. In Annex A: Built Environment. 139. Canberra: Department of Forein Affairs and Trade.

Baer, B., Bhushan, A., Taleb, H. A., Vasquez, J., \& Thomas, R. (2016). The Right to Health of Older People. The Gerontologist, 56(Suppl_2), S206-S217. doi:10.1093/geront/gnw039

Centre for Excellence in Universal Design. (2014a). Booklet 2 Entrances and Horizontal Circulation. Dublin: Centre for Excellence in Universal Design.

Centre for Excellence in Universal Design. (2014b). Booklet 3 - Vertical Circulation. Dublin: Centre for Excellence in Universal Design.

Centre for Excellence in Universal Design. (2014c). Booklet 6 - Facilities in Buildings. Dublin: Centre for Excellence in Universal Design. 
Dubai, G. o. (2017). Dubai Universal Design Code [Press release]

Equality, N. M. O. C. A. (2009). Norway Universally Designed by 2025: Action plan.

European Network on Independent Living. (2018). Severe violations of rights of disabled people in iraqi Kurdistan. Retrieved from https://enil.eu/news/severe-violations-of-rights-of-disabled-peoplein-iraqi-kurdistan/

Fleiss, J. L., Levin, B., \& Paik, M. C. (2013). Statistical Methods for Rates and Proportions: John Wiley \& Sons.

Fogarty, D. (2017). Universal Design for Learning: A New Clinical Practice Assessment Tool Toward Creating Access and Equity for all Students. (PhD), Loyola Marymount University,

Harsritanto, B. I. R. (2016). Universal Design Application through South Korea Redevelopment (A Study Review).

Jalil Abdullah, R., \& Jian, T. (2019). Using Structural Equation Modeling to Propose a Model for Shopping Complex Design Based on Universal Design Concept. Sustainability, 11(6): doi: $10.3390 /$ su1 1061797

Kadir, S. A., \& Jamaludin, M. (2012). Applicability of Malaysian Standards and Universal Design in Public Buildings in Putrajaya. Procedia-Social and Behavioral Sciences, 36: 659-669.

Koo, T. K., \& Li, M. Y. (2016). A Guideline of Selecting and Reporting Intraclass Correlation Coefficients for Reliability Research. Journal of Chiropractic Medicine, 15(2): 155-163. doi:10.1016/j.jcm.2016.02.012

Kusumarini, Y., de Yong, S., \& Thamrin, D. (2012a). Entrance and Circulation Facilities of Malls in Surabaya: A Universal Interior Design Application. Procedia - Social and Behavioral Sciences, 68: 526-536. doi: $10.1016 /$ j.sbspro.2012.12.246

Kusumarini, Y., de Yong, S., \& Thamrin, D. (2012b). Restroom Facilities of Malls in Surabaya: A Universal Interior Design Applications. Procedia - Social and Behavioral Sciences, 68: 504-514. doi:10.1016/j.sbspro.2012.12.244

Kusumarini, Y., de Yong, S., \& Thamrin, D. (2012c). Signage System of Malls in Surabaya: Universal Interior Design Applications and Suggestions for Solution. Procedia - Social and Behavioral Sciences, 68: 515-525. doi:10.1016/j.sbspro.2012.12.245
Lenker, J. A., Nasarwanji, M., Paquet, V., \& Feathers, D. (2011). A Tool for Rapid Assessment of Product Usability and Universal Design: Development and Preliminary Psychometric Testing. Work, 39(2): 141150. doi:10.3233/WOR-2011-1160

Ministry of Business Innovation and Employment. (2019a). Buildings for Everyone: Designing for Access and Usability. In Internal Circulation: Designing Buildings for Access and Usability. 1-27: Ministry of Business, Innovation and Employment.

Ministry of Business Innovation and Employment. (2019b). Buildings for Everyone: Designing for Access and Usability. In Pedestrian Circulation: Designing Buildings for Access and Usability (pp. 1-9). New Zealand: Ministry of Business, Innovation and Employment.

Oh, C. O. (2015). Development of Evaluation Tool and Guidelines of Space Design for Applying the Concept of Universal Design. Korean Institute of Interior Design Journal, 24(1): 23-33. doi:10.14774/jkiid.2015.24.1.023

Stephanidis, C., Akoumianakis, D., Sfyrakis, M., \& Paramythis, A. (1998). Universal Accessibility in HCI: Process-Oriented Design Guidelines and Tool Requirements. Paper presented at the 4th ERCIM Workshop on User Interfaces for all, Stockholm, Sweden.

Story, M. F. (1998). Maximizing Usability: The Principles of Universal design. Assistive Technology, 10(1): 4-12.

Story, M. F., Mueller, J. L., \& Mace, R. L. (1998). The Principles of Universal Design and Their Application. In The Universal Design File: Designing for People of all Ages and Abilities. 31-36. North Caroline: The Center for Universal Design.

The City of Calgary. (2010). Universal Design Handbook. Calgary, Canada: The City of Calgary Community and Neighbourhood Service (CNS) Social Policy and Planning Division.

UNAMI. (2016). Report on the Rights of Persons with Disabilities in Iraq. Retrieved from Baghdad, Iraq: https://reliefweb.int/report/iraq/report-rights-persons-disabilitiesiraq-december-2016-enar

WHO. (2013). Disability in the Southeast Asia Region. Retrieved from New Delhi, India: http://origin.searo.who.int/entity/disabilities_injury_rehabilitation/t opics/disabilityinsear2013.pdf 